\title{
Multiple mechanisms repress N-Bak mRNA translation in the healthy and apoptotic neurons
}

\author{
M Jakobson ${ }^{1}$, M Jakobson ${ }^{2}, 0$ Llano $^{3}, \mathrm{~J} \mathrm{Palgi}^{4}$ and U Arumäe ${ }^{\star, 1,4}$
}

$\mathrm{N}$-Bak is a neuron-specific BH3-only splice variant of pro-apoptotic Bcl-2 family member Bak. We have shown that its mRNA is stable in the neurons, whereas the protein cannot be detected by antibodies, suggesting a strong translational arrest of the mRNA. Here we identify two regulatory elements in the N-Bak mRNA that significantly repress translation in the luciferase reporter assay: an upstream open reading frame in the $5^{\prime}$-untranslated region (UTR) and naturally spliced exon-exon junction downstream of the premature translation termination codon in the $3^{\prime}$ UTR. We also show that N-Bak mRNA is stored in granular structures in the sympathetic neurons and stays in these granules during intrinsic apoptosis. Finally, we confirm the absence of $\mathrm{N}$-Bak protein by quantitative mass spectrometry analysis in the healthy, apoptotic or stressed sympathetic and cortical neurons. We conclude that N-Bak mRNA is translationally repressed by multiple mechanisms, and the protein does not participate in the classical apoptosis or cellular stress response.

Cell Death and Disease (2013) 4, e777; doi:10.1038/cddis.2013.297; published online 22 August 2013

Subject Category: Neuroscience

Post-transcriptional regulation of mRNA is a crucial aspect determining gene expression pattern in tissues and organs. It covers not only the splicing, modification, translation and degradation, but also stabilization, proper localization and storage of the mRNA. Many mRNAs are not translated constitutively but are stored in the repressed mode and translated only under certain conditions. Various regulatory elements in the untranslated regions (UTRs) of the mRNAs are frequently involved in the control of mRNA translation and stability, and also targeting to specific cellular compartments. In the $5^{\prime}$ UTRs, short upstream open reading frames (uORFs) and stable stem-loop secondary structures can interfere with mRNA translation. ${ }^{1-3}$ In the $3^{\prime}$ UTRs, the sequence elements can be recognized by distinct proteins or regulatory RNAs, like microRNAs (miRNAs) that can cause translational arrest of the mRNA. ${ }^{4-6}$ Also, the mRNA processing history, reflected in the exon junction complexes (EJCs) at splice junctions, is involved in mRNA localization, surveillance and translational control. ${ }^{7,8}$ Of interest, nonsense-mediated translational repression (NMTR) has recently been described, ${ }^{9,10}$ where EJC in the context of premature termination codon (PTC) represses $m R N A$ translation without affecting its level. Thus, the interplay of various RNA-binding factors and mRNA-specific regulatory elements determine the post-transcriptional fate of the mRNA.

Bak is the $\mathrm{BH} 1-3$ pro-apoptotic member of the $\mathrm{Bcl}-2$ protein family that, together with the related protein Bax, triggers mitochondrial changes in the intrinsic apoptosis. ${ }^{11}$ When activated, Bak and Bax generate pores on the mitochondrial outer membrane ${ }^{12}$ whereby the mitochondrial proteins (cytochrome $c$, DIABLO/Smac, EndoG, AIF and so on) are released to the cytosol to advance apoptosis. ${ }^{13,14}$ We have shown ${ }^{15,16}$ that unlike all other studied cells, neurons do not express Bak as its pre-mRNA is entirely spliced into mRNA encoding a putative $\mathrm{BH} 3-$ only protein, named N-Bak. Thus, the neurons express only Bax, ${ }^{15-19}$ and their mitochondrial apoptosis depends solely on Bax. ${ }^{20}$ In the same studies ${ }^{15,16}$ we demonstrated that, despite the presence of mRNA, N-Bak protein is not detectable in the brain or cultured primary neurons. We also showed ${ }^{16}$ that the absence of N-Bak protein is not caused by rapid degradation of its mRNA or proteasome-mediated degradation of the protein. Instead, the N-Bak mRNA appears to be stabile suggesting its translational arrest and storage in the neurons.

Here, we set up to address the mechanisms of N-Bak mRNA repression more in detail. We identified an inhibitory uORF at the 5'UTR of N-Bak mRNA that represses luciferase reporter translation. Also, a naturally spliced exon-exon junction downstream of PTC in the $3^{\prime}$ UTR of N-Bak mRNA strongly represses translation of the luciferase reporter. We show that endogenous N-Bak mRNA is localized to granular structures in the neurons. Importantly, endogenous N-Bak mRNA was not translated in the neurons during mitochondrial apoptosis or cellular stress, as shown by antibodies and quantitative mass spectrometry analysis, suggesting specific and robust translational arrest.

\footnotetext{
${ }^{1}$ Institute of Biotechnology, University of Helsinki, FIN-00014, Helsinki, Finland; ${ }^{2}$ Max Planck Institute of Biochemistry, Department of Molecular Medicine, 82152, Martinsried, Germany; ${ }^{3}$ Neuroscience Center, University of Helsinki, FIN-00014, Helsinki, Finland and ${ }^{4}$ Department of Gene Technology, Tallinn University of Technology, Akadeemia tee 15, Tallinn, 12618, Estonia

*Corresponding author: U Arumäe, Institute of Biotechnology, Viikki Biocenter, University of Helsinki, P.O. Box 56, FIN-00014, Helsinki, Finland. Tel: + 3589 19159396; Fax: + 3589 19159366; E-mail: urmas.arumae@ @elsinki.fi

Keywords: N-Bak; translational repression; PTC; UORF; UTR; NMTR

Abbreviations: NGF, nerve growth factor; SCG, superior cervical ganglion; UTR, untranslated region; uORF, upstream open reading frame; EJC, exon junction complex; LNA, locked nucleic acid; DIV, days in vitro; PTC, premature stop codon; NMD, nonsense-mediated decay; NMTR, nonsense-mediated translational repression; Fluc, Firefly luciferase; Rluc, Renilla luciferase; eGFP, enhanced green fluorescent protein

Received 04.4.13; revised 28.6.13; accepted 04.7.13; Edited by A Verkhratsky
} 


\section{Results}

Regulatory elements of the N-Bak mRNA UTRs that repress its translation. To ascertain regulatory elements in the UTRs of N-Bak mRNA that could participate in its translational repression, we prepared reporter constructs where the UTRs with or without mutations in the candidate control regions were fused upstream or downstream of Firefly luciferase (Fluc) coding sequence (Figure 1). Sympathetic neurons were microinjected with these constructs together with the Renilla luciferase (Rluc) reporter plasmid and relative luciferase activities were measured $48 \mathrm{~h}$ later. In addition, the mouse neuroblastoma Neuro-2a cells were transfected with reporters and analyzed for the relative luciferase activities and reporter mRNA levels. Because of limited amount of the material, reporter mRNA levels were not analyzed from microinjected primary neurons.

Mouse Bak mRNA (NM_007523.2) (Figure 1) has a 5'UTR of 253 nucleotides, present in both Bak and N-Bak transcripts. The $5^{\prime}$ UTR of Bak mRNA is not well conserved, but different species contain one or two uORFs, some with weak Kozak consensus sequence. We cloned full-length $5^{\prime} U T R$ in front of the Fluc reporter gene ( $5^{\prime}$ UTR-Fluc, Figure 1$) .{ }^{16}$ We choose to address the 189-nucleotide uORF in the mouse Bak/N-Bak mRNAs as its initiator AUG is in the context of the Kozak consensus sequence, whereas the second AUG of the $5^{\prime}$ UTR lies within the first uORF and lacks the Kozak sequence. We deleted a 38-nucleotide region from the N-Bak 5'UTR encompassing the AUG of the first uORF (5'UTRmut-Fluc, Figure 1). This deletion significantly increased luciferase activity compared with the wild-type $5^{\prime}$ UTR (5'UTR-Fluc) in both cell types (Figures $2 a$ and $b$ ). This is in line with our previous results showing the importance of Bak 5'UTR on the translation of luciferase reporter in the superior cervical ganglion (SCG) neurons. ${ }^{16}$ Transcript levels for both $5^{\prime}$ UTR reporters, analyzed from transfected Neuro-2a samples by quantitative RT-PCR, were similar (Figure 2h). Hence, the $5^{\prime} \mathrm{uORF}$ significantly represses translation in the luciferase reporter assay and may inhibit translation of the main ORF on the N-Bak mRNA in the neurons.

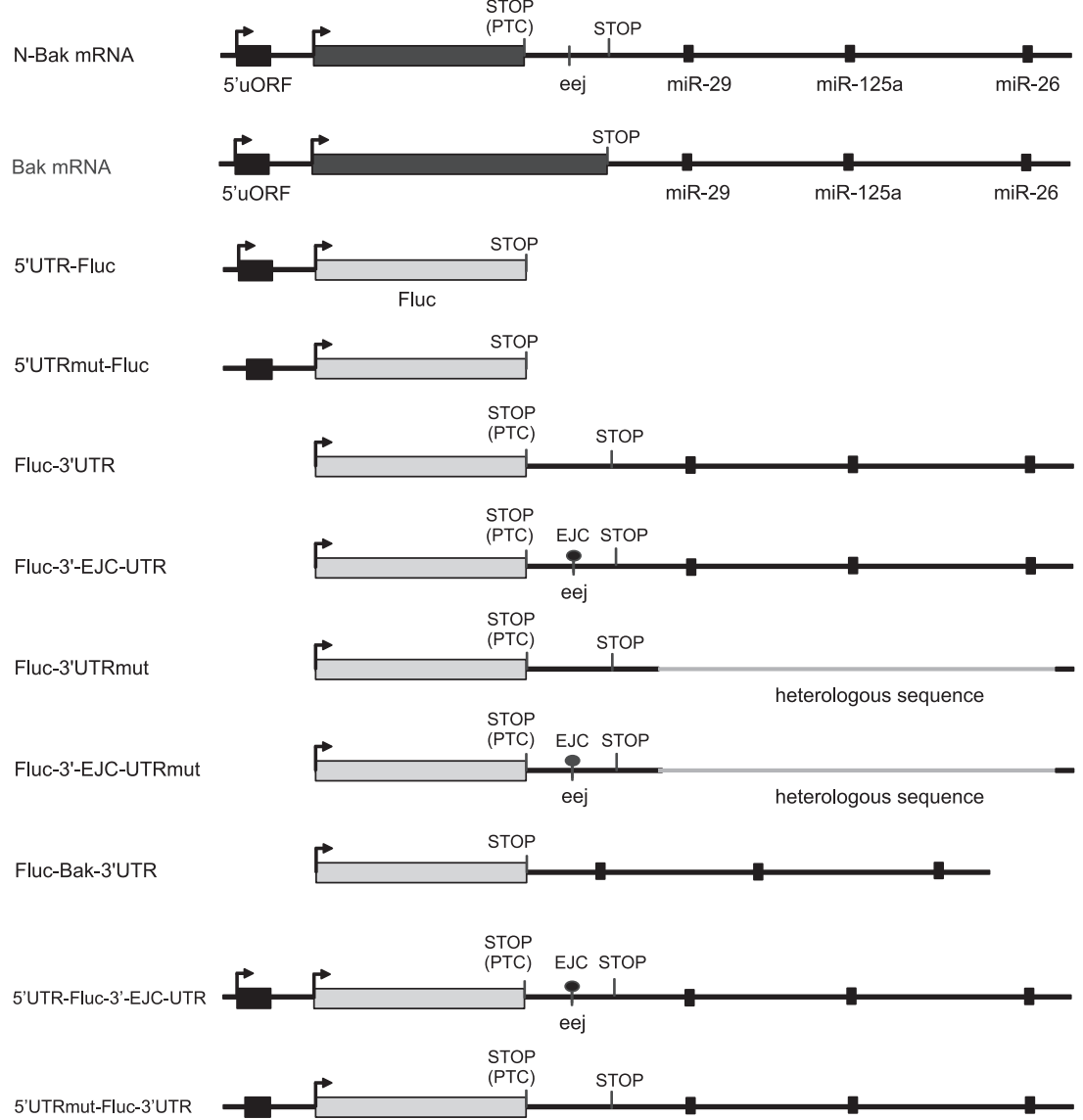

Figure 1 Diagram of Firefly luciferase reporter constructs used in the study. Two upper schemes present N-Bak and Bak mRNAs with $5^{\prime}$ upstream ORFs ( $\left.5^{\prime} u O R F\right)$ and coding regions (black boxes), stop codon (STOP) and predicted microRNA sites on the $3^{\prime} U T R$ (black squares) are shown on the top. For N-Bak mRNA the addressed exonexon junction (eej) and premature termination codon (PTC) are also shown. Lower schemes illustrate the reporter constructs. Firefly luciferase coding region (Fluc) is shown as a gray box. $5^{\prime}$ UTRmut, deletion of 38 nucleotides from the $5^{\prime} U T R$, including the initiation codon for the UORF. $3^{\prime} U T R$ mut, the construct where the $3^{\prime} U T R$ region containing the predicted microRNA target sites is replaced with the heterologous sequence (gray line) about the same length. Fluc-Bak- $3^{\prime} U T R$, the construct where the 191 nucleotides between the two stop codons 20 are not included. Also construct with wild-type $5^{\prime}$ UTR and $3^{\prime} U T R$, named $5^{\prime} U T R$-Fluc-EJC-3'UTR, and construct carrying mutated critical regulatory elements in both UTRs, named 5'mutUTR-Fluc-3'UTR, are shown. EJC, the putative exon junction complex deposited at the eej after splicing off the 131-nucleotide intron (for clarity, intron is not shown on the scheme) 

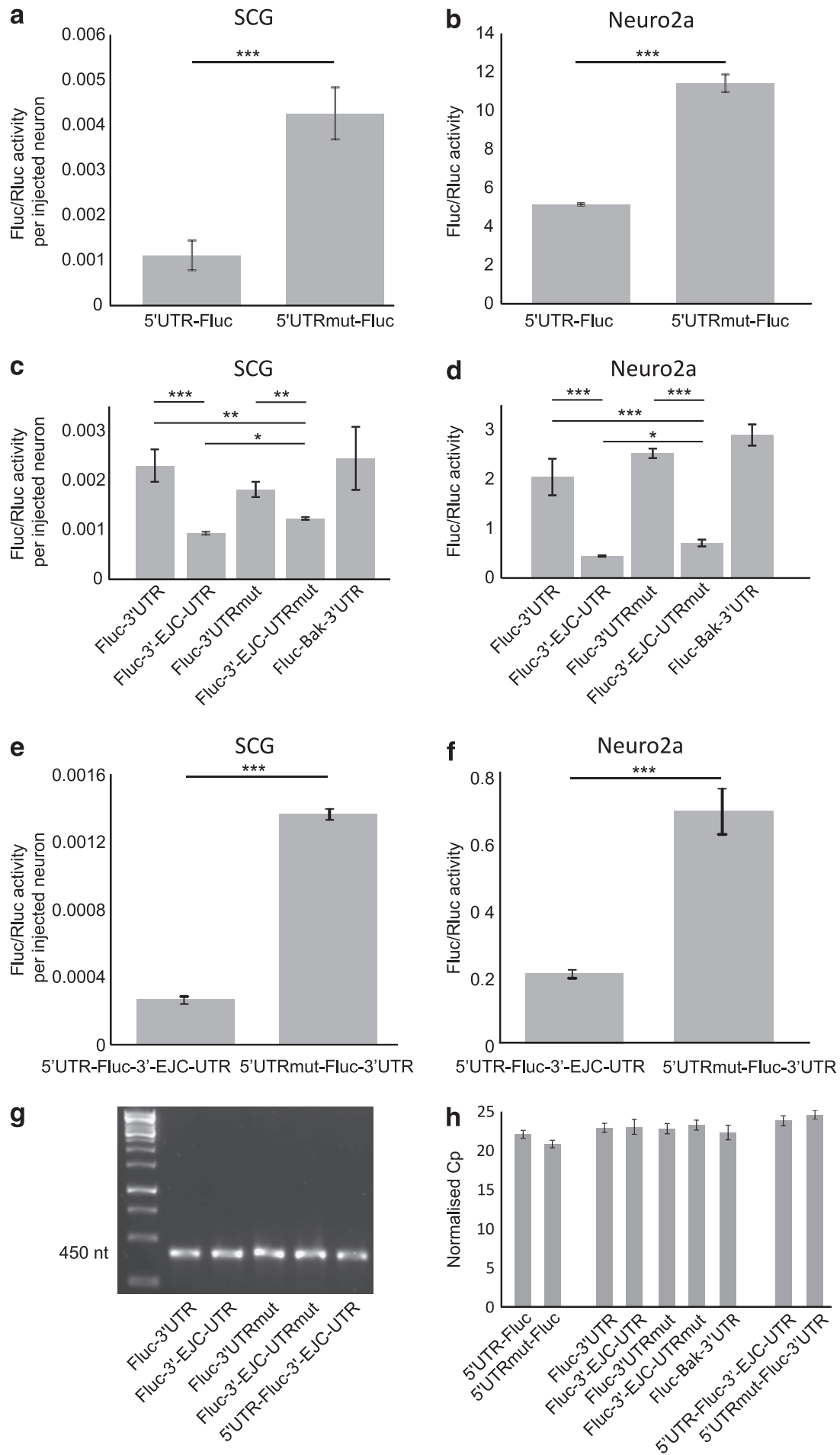

Figure 2 Dual luciferase reporter assays. Relative luciferase activities measured from the SCG neurons (a, $\mathbf{c}$, and $\mathbf{e})$ or Neuro-2a cells $(\mathbf{b}$, $\mathbf{d}$, and $\mathbf{f})$ overexpressing the indicated reporter constructs. The neurons (3-4 repeats on the independent cultures) were microinjected with the reporter plasmids together with the plasmid for eGFP. The ratio of Firefly and Renilla luciferase (Fluc/Rluc) activity was determined $48 \mathrm{~h}$ later and was normalized to the number of eGFP-positive neurons, counted before the lysis. The Neuro-2a cells ( 6 repeats on the independent cultures) were transiently transfected and the Fluc/Rluc activity determined $48 \mathrm{~h}$ later. Shown are the means \pm S.E.M. Statistical significance of the differences was estimated by Student's t-test (a and $\mathbf{b})$ or one-way ANOVA and post hoc Tukey's test $(\mathbf{b}$ and $\mathbf{c})$. ${ }^{*} P<0.05,{ }^{* *} P<0.01$, ${ }^{* * \star} P<0.001$, the null hypothesis was rejected at $P<0.05$. (g) RT-PCR analysis of the indicated constructs with and without the 131-nucleotide intron in transiently transfected Neuro-2a cells using primers flanking the exon-exon junction sequence. Equal sizes of the amplified fragments show that the intron was correctly removed by splicing. Shown is the Fermentas GeneRuler 1-kb DNA Ladder molecular weight marker. (h) Quantitative RT-PCR analysis of the indicated constructs in transiently transfected Neuro-2a cells. Shown are the $\mathrm{Cp}$ values of Fluc constructs normalized to Rluc values (means \pm S.E.M. of three independent experiments). There were no significant differences between the groups (one-way ANOVA and post hoc Tukey's test) 
Differently from Bak, $3^{\prime}$ UTR of the N-Bak mRNA harbors a PTC in the second last exon followed by downstream exon-exon junction (Figure 1). Proteins of the EJC downstream of PTC can direct mRNA to rapid degradation via nonsense-mediated decay (NMD) or, in contrary, lead to repression of $m R N A$ translation via NMTR without affecting its stability. ${ }^{9,10}$ We tested if premature termination context in the $\mathrm{N}$-Bak $3^{\prime} \mathrm{UTR}$ affects mRNA translation in the luciferase reporter assay. Three $3^{\prime} U T R$ reporter constructs were generated (Figure 1). N-Bak $3^{\prime}$ UTRs, with and without a 131-nucleotide intron between exons 5 and 6 , were cloned downstream of the Fluc stop codon (Fluc-EJC-3'UTR and Fluc-3'UTR respectively, Figure 1). Splicing of the intron in Fluc-EJC-3'UTR should lead to EJC deposition near the spliced site and the stop codon of Fluc would be recognized as PTC, thus mimicking a natural $3^{\prime}$ UTR of N-Bak mRNA. Third construct with full-length Bak 3'UTR (Fluc-Bak-3'UTR, Figure 1), starting from its natural stop codon, was also cloned downstream of Fluc and served as a control. RT-PCR analysis with primers flanking exon-exon junction sequence in the N-Bak $3^{\prime}$ UTR reporters Fluc-EJC- $3^{\prime}$ UTR and Fluc-3'UTR revealed equal lengths of PCR products, confirming correct splicing of Fluc-EJC-3'UTR transcripts in the transiently transfected Neuro-2a cells (Figure $2 \mathrm{~g}$ ). Quantitative PCR analysis revealed equal mRNA levels for all $3^{\prime} U T R$ reporters, indicating that PTC context in the $3^{\prime} U T R$ does not affect reporter mRNA level in the transiently transfected Neuro-2a cells (Figure 2h). Importantly, the spliced Fluc-EJC-3'UTR showed significantly reduced luciferase activity compared with the intronless reporter Fluc-3'UTR or Fluc-Bak-3'UTR control in both SCG neurons and Neuro$2 a$ cells (Figures $2 \mathrm{c}$ and $d$ ). Thus, spliced exon-exon junction downstream of PTC, the special feature of the $3^{\prime} U T R$ of N-Bak but not Bak mRNA, strongly represses translation of the luciferase reporter and may also contribute to translational repression of N-Bak mRNA in vivo. Fluc-3'UTR and FlucBak-3'UTR did not show significant differences in the luciferase activity in either cell type (Figures $2 c$ and d), indicating that the sequence between two stop codons in the $\mathrm{N}-\mathrm{Bak} 3^{\prime} \mathrm{UTR}$ is not a determinant for translational repression. Reporter construct with both $5^{\prime}$ UTR and $3^{\prime}$ UTR of N-Bak mRNA, that is, having intact UORF and exon-exon junction (5'UTR-Fluc-3'-EJC-UTR), showed significant decrease in luciferase activity values in the SCG neurons and Neuro2a cells, compared with similar reporter construct harboring mutated UORF in the $5^{\prime}$ UTR and absence of exon-exon junction in the $3^{\prime} U T R$ (Figures $2 e$ and f). Both reporter constructs had equal mRNA levels (Figure $2 \mathrm{~h}$ ).

TargetScan 5.1 (http://www.targetscan.org/, release 6, 2 June 2012) predicts conserved binding sites for miR-29abcd (UGGUGCUA), miR125ab-5p (CUCAGGGA) and miR26ab (UACUUGAA) on the $3^{\prime}$ UTR of Bak mRNA. We next explored the role of miRNA sites in mediating repression of reporter mRNA translation. We used Fluc-EJC- 3'UTR and Fluc-3'UTR reporters and replaced the region encompassing all three predicted microRNA sites with the heterologous sequence about the same length, resulting in two reporter constructs, Fluc-3'UTRmut and Fluc-EJC-3'UTRmut (Figure 1). Transcript levels of both constructs were similar in transiently transfected Neuro-2a cells (Figure 2h). RT-PCR with intron flanking primers showed equal lengths for both reporter mRNAs, confirming that Fluc-EJC-3'UTR was correctly spliced. In the context of spliced reporter transcript, Fluc-EJC-3'UTRmut, the luciferase activity was increased in a small but significant scale in both cell types, compared with Fluc-EJC-3'UTR (Figures 2c and d), whereas intron-free reporter Fluc-3'UTRmut had luciferase activity similar to that of Fluc-3'UTR (Figures $2 c$ and d). Thus, miRNA binding sites mediated slight repressive effect on translation of the Fluc reporter, but only in the context of spliced $3^{\prime} U T R$.

We conclude that two sequence elements of N-Bak mRNA, namely uORF in the 5'UTR and exon-exon junction downstream of PTC in the $3^{\prime} U T R$, have strong repressive effects on its translation. Also, miRNAs may potentially contribute to $\mathrm{N}$-Bak mRNA translational repression in the neurons.

N-Bak mRNA has granular localization in the SCG neurons. Translationally repressed mRNAs are often compartmentalized in the cell to allow orchestrated control through interaction with specific regulatory factors and processing enzymes. ${ }^{21-24}$ We studied the intracellular localization of endogenous N-Bak mRNA in the sympathetic neurons from the SCG by in situ hybridization, utilizing locked nucleic acid (LNA) oligonucleotide probes designed specifically to detect a 20-nucleotide exon $\mathrm{N}$ within the $\mathrm{N}$-Bak mRNA. The sense probe for exon $\mathrm{N}$ served as the negative control. As shown in Figure 3, N-Bak-specific LNA probe hybridized to punctate, granular structures. Such granules were observed in all neurons, most densely located in the soma, whereas the nuclei were essentially free of them. The sense probe gave mostly faint diffuse signal (Figure 3) with some scattered dots that were always sparse, whereas the antisense probe-hybridized neurons always exhibited dense granular pattern. Nonneuronal cells lacking N-Bak mRNA were always free of signal (not shown).

To analyze whether the N-Bak mRNA is stored in the P-bodies, the known storage/degradation sites of translationally repressed mRNAs, we attempted to colocalize it with Dcp $1 \alpha$, the marker of P-bodies. We first injected the SCG neurons with plasmid encoding for GFP-Dcp1 $\alpha$ fusion protein. Subsequent immunostaining with anti-Dcp $1 \alpha$ antibody revealed the specificity of the antibodies as they clearly recognized GFP-Dcp $1 \alpha$ fusion proteins (Figures $4 a-d$ ). These antibodies were then used to immunostain the neurons hybridized with N-Bak LNA probes. The N-Bak mRNA-containing granular structures and endogenous Dcp $1 \alpha$-positive signal did not colocalize (Figures $4 e-h)$. Thus, $\mathrm{N}$-Bak mRNA is associated with the granules whose identity remains currently elusive.

$\mathrm{N}$-Bak protein is not found in the healthy, apoptotic or stressed neurons. N-Bak protein is not detectable by immunoblot in the healthy or apoptotic neurons, ${ }^{15,16}$ suggesting that its mRNA is not translated. However, we cannot exclude technical insufficiency to detect N-Bak protein by antibodies. We therefore turned to quantitative mass spectrometry as an independent approach. The samples of the cultured SCG and cortical neurons were separated on two parallel gels, one used for immunoblot and another for mass spectrometry. In the immunoblot, anti-Bak 


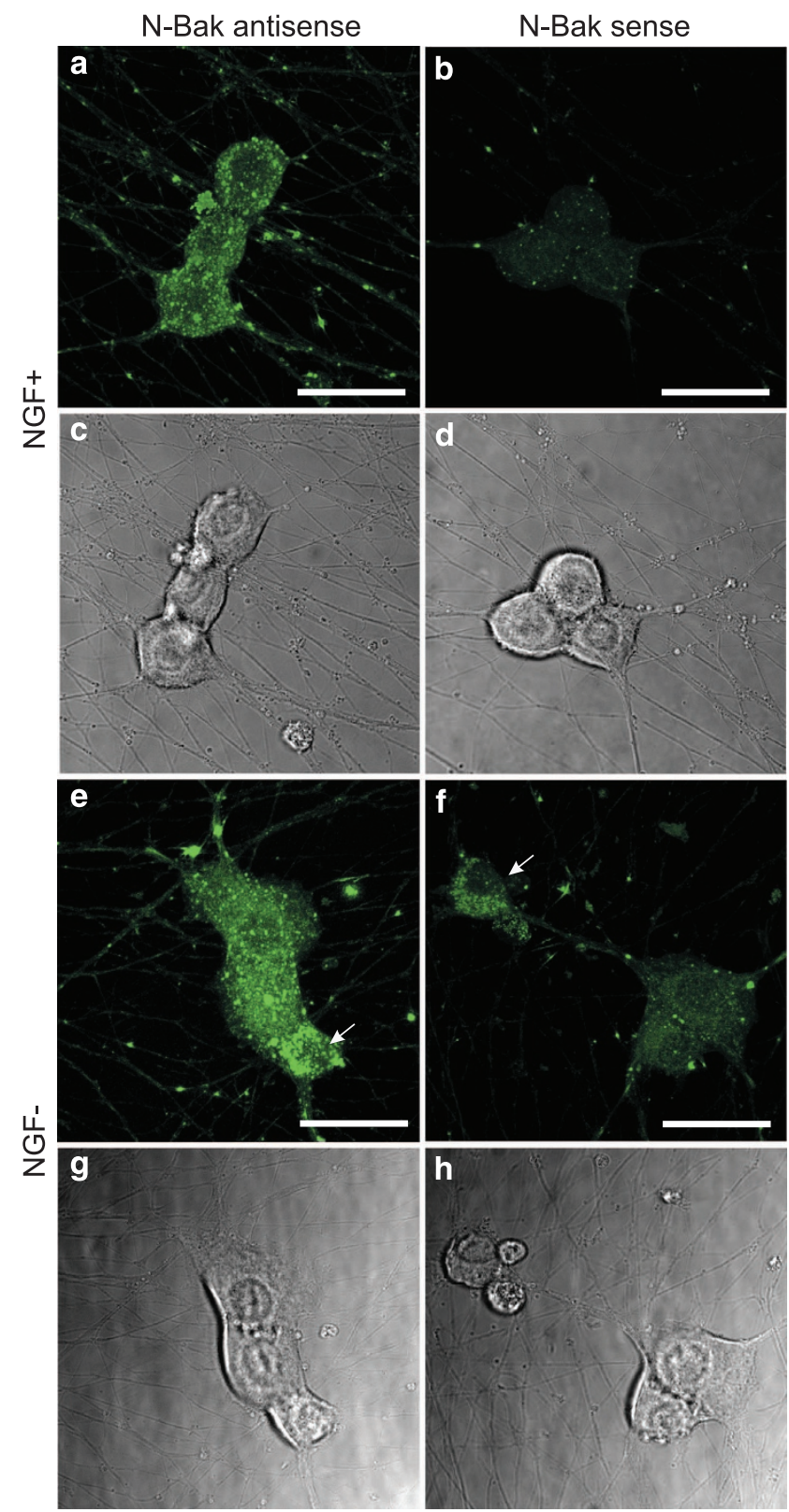

Figure 3 Granular localization of N-Bak mRNA in the SCG neurons. The 5 DIV SCG neurons grown with NGF (a-d) or deprived of NGF for $24 \mathrm{~h}(\mathbf{e}-\mathbf{h})$ and hybridized with N-Bak-specific LNA oligonucleotide probes in the antisense (a and $\mathbf{e}$ ) or sense (b and f) orientation. Shown are the deconvoluted merged stacks of confocal microscopic images of typical neurons. Corresponding phase-contrast images are also shown. On both antisense-hybridized (e) and sense-hybridized (f) images of NGF-deprived neurons, a pyknotic cell with typical strong background hybridization signal is shown (arrow). Scale bar, $25 \mu \mathrm{m}$

antibodies again did not recognize $\mathrm{N}$-Bak from the healthy SCG neurons (Figure 5a, NGF + lane), although a $\mathrm{N}$-Bak-specific band of $\sim 20 \mathrm{kD}$ was detected from the sample of N-Bak-L76E-transfected HeLa cells (Figure 5a, $\mathrm{N}$-Bak-L76E lane). In the cortical neuron samples, a band of $\sim 21 \mathrm{kD}$ was noticed (Figure $5 \mathrm{a}$ ). We have observed this band occasionally in some cortical culture samples, but never in the samples of SCG neurons. The regions corresponding to the size of N-Bak protein but excluding the regions for Bak protein were cut out from the parallel gel of the same samples (Figure 5) and analyzed by quantitative mass spectrometry. Notably, N-Bak protein was not found in the neuronal samples but was identified only in the sample of the HeLa cells overexpressing it (not shown). Thus, two independent techniques confirmed the absence of N-Bak protein in the healthy SCG and cortical neurons. The protein of $\sim 21 \mathrm{kD}$ in the cortical cultures appears to be nonspecifically recognized by the anti-Bak antibodies.

We conclude that N-Bak mRNA is translationally repressed in the neurons. We also reasoned that this repression could be released during apoptosis or under cellular stress. BH3-only proteins are induced or activated in the intrinsic apoptotic pathway. ${ }^{25}$ Of interest, the intrinsic apoptosis induced by cellular stress is preceded by increased phosphorylation of $\alpha$-subunit of the eukaryotic translation initiation factor 2 (elF2 $\alpha$ ), leading to increased translation of certain mRNAs, often via short uORFs in their $5^{\prime}$ UTRs. ${ }^{26,27}$ We tested whether $\mathrm{N}$-Bak protein could be induced in the apoptotic or stressed neurons using immunoblot and mass spectrometry techniques. Cellular stress was induced in the cortical neurons by thapsigargin, an inhibitor of sarco/endoplasmic reticulum $\mathrm{Ca}^{2+}$ ATPases, that causes endoplasmic reticulum stress because of $\mathrm{Ca}^{2+}$ depletion and causes subsequent activation of intrinsic apoptotic pathway. Treatment of neurons with $10 \mathrm{nM}$ of thapsigargin for $1 \mathrm{~h}$ induced maximal level of elF $2 \alpha$ phosphorylation (Figure $5 \mathrm{~b}$, upper panel) and these conditions were used in the following experiments. To induce mitochondrial apoptosis, we deprived SCG neurons of nerve growth factor (NGF) for $48 \mathrm{~h}$ or treated cortical neurons with $4 \mu \mathrm{g} / \mathrm{ml}$ of etoposide, the inhibitor of topoisomerase II, for $24 \mathrm{~h}$. All treatments were done in the presence of caspase inhibitors. As shown by immunoblot, N-Bak protein was not induced by any of these treatments (Figure $5 \mathrm{a}$ and lower panel of Figure $5 b$ ). The absence of N-Bak protein in the samples of Figure 5 a was confirmed by quantitative mass spectrometry analysis (not shown). Thus, translational repression of N-Bak mRNA is not released in the neurons during classical apoptotic or cellular stress conditions.

We also checked whether the N-Bak-positive granular structures were lost during mitochondrial apoptosis. To that end, we deprived the SCG neurons of NGF for $24 \mathrm{~h}$ and blocked the death by caspase inhibitor BAF. By that time, the apoptotic mitochondrial changes such as translocation of Bax to the mitochondria and release of cytochrome $c$ to the cytosol had already occurred in the majority of the neurons ${ }^{28-31}$ and the $\mathrm{BH}$ 3-only proteins should have been activated, ${ }^{32}$ as shown for DP5/Hrk, ${ }^{33,34}$ Bim $^{35,36}$ and PUMA. ${ }^{37}$ The cultures were then hybridized with N-Bak-specific LNA probes in the antisense or sense orientation as above. The dense $\mathrm{N}$-Bak-containing granules were still clearly visible in the neurons as exemplified on Figure $3 e$, whereas the senseprobe again revealed only sparse signal (Figure 3 f). It must be noted that when the neurons become highly pyknotic, they bound strongly both antisense and sense LNA probes (Figures $3 e$ and f), most probably nonspecifically. However, before this stage, all neurons showed granular pattern of $\mathrm{N}$-Bak mRNA. In summary, we conclude that N-Bak mRNA is not released from repression during classical mitochondrial 

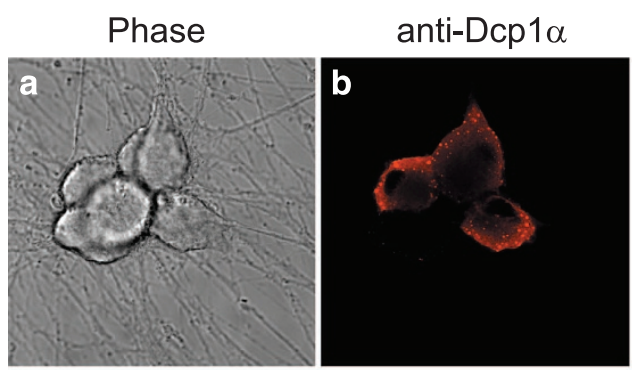

Phase
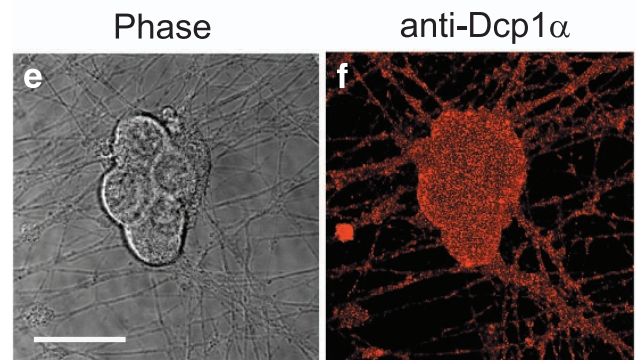

GFP-Dcp1 $\alpha$

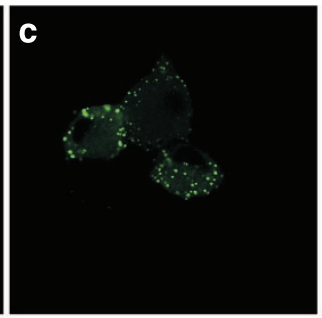

N-Bak antisense

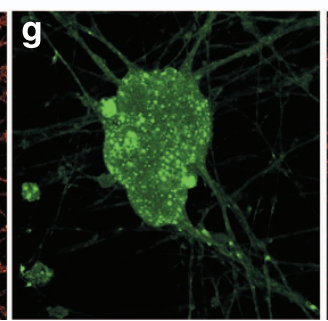

Merged

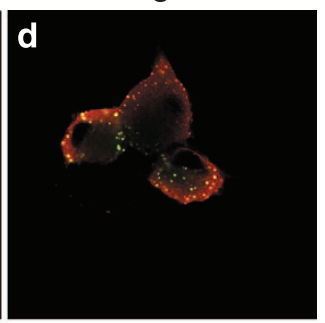

Merged

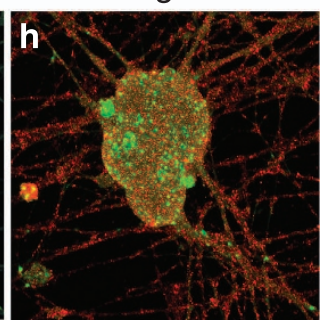

Figure 4 N-Bak mRNA is not localized to P-bodies in the SCG neurons. (a-d) Anti-Dcp1 $\alpha$ antibody recognizes its antigen. Shown are three SCG neurons overexpressing GFP-Dcp1 $\alpha(\mathbf{b})$ and immunostained with anti-Dcp1 $\alpha$ antibody (c). The corresponding phase-contrast image (a) and merged image (d) are also shown. Note that all GFP-Dcp $1 \alpha$ granules are recognized by anti-Dcp $1 \alpha$ antibody. The endogenous Dcp $1 \alpha$ is not visible because of underexposure. (e-h) Deconvoluted merged stacks of confocal microscopic images of typical neurons colabeled with anti-Dcp1 $\alpha$ antibodies, the marker for the P-bodies (f) and N-Bak-specific LNA probe (g). Corresponding phase-contrast image (e) and merged image (h) are also shown. Note that the granules do not colocalize. Scale bar, $25 \mu \mathrm{m}$

apoptosis caused by NGF deprivation, in good agreement with our findings of the general absence of N-Bak protein.

\section{Discussion}

In this study, we show that the mRNA for N-Bak is under strong translational repression in neurons. The evidences for this conclusion are as follows: (1) 5'UTR and $3^{\prime}$ UTR of N-Bak mRNA contain regulatory elements (inhibitory uORF and PTC with downstream splice junction, respectively) that strongly repress translation in the luciferase reporter assay; (2) endogenous N-Bak mRNA is stored in the granular structures; and (3) N-Bak protein cannot be detected in the healthy and apoptotic/stressed neurons by two independent techniques. Together with our earlier findings that N-Bak mRNA is stable and not rapidly degraded, ${ }^{16}$ these data strongly suggest a stable translational repression of N-Bak mRNA in the neurons, and that N-Bak does not contribute to classical mitochondrial apoptosis.

We show that presence of exon-exon junction downstream of PTC on the N-Bak $3^{\prime} \mathrm{UTR}$ is repressive to the reporter mRNA translation, whereas reporter mRNA levels were not affected. Translational repression and stabilization of mRNA via PTC and downstream EJC has been described as NMTR. ${ }^{9,10,38}$ Thus, our data suggest that N-Bak mRNA is subjected to NMTR rather than to $\mathrm{NMD}^{16}$ by these mRNA elements. The mechanism of NMTR remains elusive, but the EJC core protein elF4AIII was required, whereas the NMD factors Upf1 and Upf2 were not. ${ }^{9,10}$ Premature termination context is missing in the $\mathrm{BH} 1-3$ Bak mRNA, in good agreement with its translation in the nonneuronal cells.

UORF in the $5^{\prime}$ UTR of N-Bak mRNA also represses the luciferase reporter translation. The mechanism of such repression remains to be studied. Generally, the 405 ribosome subunit can bypass the upstream AUGs and initiate translation at the AUG of the main ORF, often by leaky scanning and reinitiation or by scanning through the uORFs. 2,3,39,40 In some poorly defined cases, the uAUGs and UORFs can prevent translation, probably by restricting the access of ribosomes to the initiation codon of the main ORF. ${ }^{2,3,39,41}$ However, the uORFs usually reduce translation rather than block it altogether, ${ }^{42}$ whereas the N-Bak mRNA in the neurons seems to be totally arrested. Also, the Bak mRNA is translated in the nonneuronal cells despite the uORF. Therefore, it seems unlikely that the uORF is the main mechanism of translational repression for N-Bak mRNA. However, cooperation of mRNA 5'UTR and $3^{\prime}$ UTR contributes to many regulatory processes in mRNA biology. ${ }^{43,44}$ We show that simultaneous presence of $\mathrm{N}$-Bak $5^{\prime} \mathrm{UTR}$ with mutated UORF and $3^{\prime} U T R$ with deleted regulatory intron in the luciferase reporter mRNA lead to significantly higher luciferase expression values than the reporter construct with intact N-Bak UTRs. This result suggests that $5^{\prime} U T R$ and $3^{\prime} U T R$ might cooperate in the repression of N-Bak mRNA in the neurons.

When analyzing the effect of mutated miRNA-binding region in N-Bak $3^{\prime} \mathrm{UTR}$ to reporter translation, we detected minor increase in luciferase activities, which was significant only in the reporter mimicking natural N-Bak $3^{\prime} U T R$. Although the effect was small, the role of miRNAs in the repression of endogenous N-Bak mRNA should not be underestimated. For example, the overexpressed reporter constructs may highly exceed the capacity of miRNAs available in the neurons such that their possible effects remain below detection. Recently others ${ }^{45}$ have shown that miR29b can repress the mRNAs for several BH3-only proteins, including N-Bak, in mature SCG neurons. In that study the repressive effect was studied using both the luciferase reporter and exogenous miR29b 


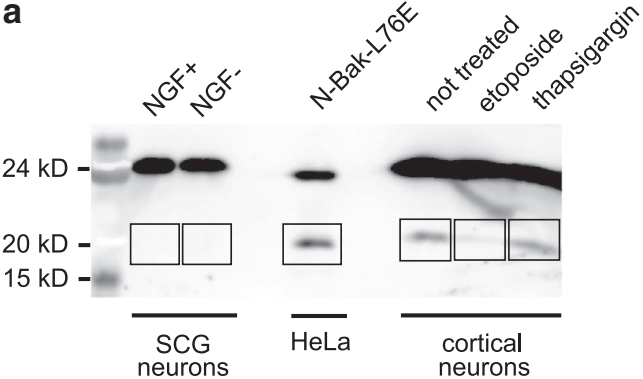

b

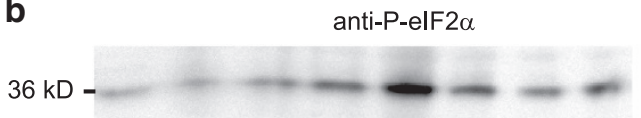

anti-Bak

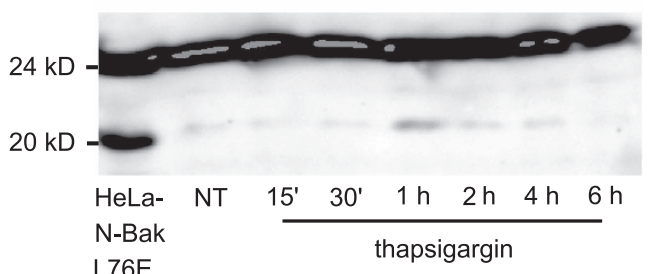

Figure $5 \mathrm{~N}$-Bak protein is not induced in the apoptotic or stress conditions. (a) The 5 DIV SCG neurons were deprived of NGF for 2 days in the presence of caspase inhibitor BAF, or not deprived. The 6 DIV cortical neurons were treated for $24 \mathrm{~h}$ with $4 \mu \mathrm{g} / \mathrm{ml}$ of etoposide or for $1 \mathrm{~h}$ with $10 \mathrm{nM}$ of thapsigargin in the presence of caspase inhibitor Q-VD-OPh, or left untreated. Immunoblot was probed with anti-Bak antibodies. The position of $\sim 20 \mathrm{kD} \mathrm{N}$-Bak is shown on the lane of HeLa cells overexpressing the apoptotically inactive L76E mutant. Note the absence of $\sim 20 \mathrm{kD} \mathrm{N}$-Bak protein in the SCG neurons and the presence of $\sim 21 \mathrm{kD}$ nonspecific band on the lanes of cortical neurons. The boxed areas were cut from the parallel gel and analyzed by mass spectrometry. (b) Cortical neurons were treated with $10 \mathrm{nM}$ of thapsigargin in the presence of caspase inhibitor QVD-OPh for the indicated times, or not treated (NT). Immunoblot was probed with antibodies to PelF2 $\alpha$ (upper panel), known to be increasingly phosphorylated in the endoplasmic reticulum stress, and reprobed with anti-Bak antibodies (lower panel). The position of $\sim 20 \mathrm{kD} \mathrm{N}-\mathrm{Bak}$ is shown on the lane of HeLa cells overexpressing the apoptotically inactive L76E mutant (HeLa-N-BakL76E). The Bak protein of $\sim 25 \mathrm{kD}$ in (a) and (b) comes from the nonneuronal cells in the cultures and its signal is overexposed

constructs in transfected HEK293T cells, whereas we studied the exogenous reporter constructs in the natural neuronal milieu. Validation of the role of miRNAs in translational repression of the N-Bak mRNA requires further studies that are, however, challenging in the primary neurons.

In the actively growing, unstressed cells, P-bodies concentrate proteins not only involved in the translational repression, surveillance and degradation of the mRNAs, but also miRNA-mediated mRNA silencing. ${ }^{46} \mathrm{~N}$-Bak mRNA does not colocalize with P-body marker Dcp $1 \alpha$, indicating that it is directed to some other type of granular structures, most probably for translational silencing and storage. Indeed, diverse granules have been described in different cells, including the neurons, but their identity and biology is not well understood. ${ }^{47-50}$ Nevertheless, as different RNA granules are known to contain translationally inactive mRNAs, storage of the N-Bak mRNA in the cytoplasmic granules could be an additional mechanism for its translational control.
In summary, N-Bak mRNA translation seems to be controlled via multiple mechanisms, including repression by uORF, premature termination context and also potentially by miRNAs. Possible synergy between multiple regulatory elements may lead to deposition of N-Bak mRNA into cytoplasmic granules where its fate can be further controlled by mechanisms that remain currently unknown and need to be addressed in further studies.

The complete absence of $\mathrm{N}$-Bak band in our immunoblots was remarkable, raising doubts that it could result from technical complications. For example, the $\mathrm{N}$-terminal epitope on endogenous N-Bak, the epitope for most anti-Bak antibodies, could be modified and therefore not recognized any more. The anti-Bak antibodies against other epitopes did not recognize overexpressed (and endogenous) N-Bak. ${ }^{16}$ We confirmed the absence of $\mathrm{N}$-Bak protein by quantitative mass spectrometry analysis that did not detect any N-Bak peptide from healthy, apoptotic or stressed neurons. We also subjected the cortical neurons to hypoxic stress or glucoseoxygen deprivation. Still, no N-Bak protein was found in these samples, neither by immunoblot nor by mass spectrometry ( $M$ Jakobson and $M$ Jakobson, unpublished data). Thus, two independent techniques clearly demonstrate that endogenous $\mathrm{N}$-Bak mRNA is indeed not translated under tested conditions. Moreover, the translational block is complete, as even sensitive mass spectrometry did not detect any sign of $\mathrm{N}$-Bak protein. A nonspecific band close to the size of N-Bak was occasionally recognized by anti-Bak antibodies from the cortical neuron samples, and its level was changed under some stress conditions. We do not know the identity of this protein, but as it was observed inconsistently, it may origin from the nonneuronal cells whose numbers vary from culture to culture. Possibly the same nonspecific band was reported earlier by others as $\mathrm{N}-\mathrm{Bak}$ in the cortical cultures. ${ }^{17}$

By common understanding, the mRNAs are translationally suppressed only transiently and released from the repression in the relevant conditions. ${ }^{47-51}$ We were surprised to find that $\mathrm{N}$-Bak protein was not induced in the apoptotic and stressed neurons where such BH3-only protein could be required. Thus, the neurons totally repress N-Bak mRNA and N-Bak does not contribute to classical mitochondrial apoptosis in the neurons. By our current model, the neurons entirely avoid both isoforms of Bak: the mRNA for $\mathrm{BH} 1-3$ Bak is removed by complete alternative splicing, and the resulting mRNA for $\mathrm{BH} 3-$ only $\mathrm{N}$-Bak is translationally completely repressed. Whether the N-Bak mRNA is ever released from translational block is currently unclear.

\section{Materials and Methods}

Cloning and expression plasmids. N-Bak 5'UTR-FF-Luc reporter plasmid, published earlier ${ }^{16}$ is named here as $5^{\prime}$ UTR-Fluc and it was used to generate $5^{\prime}$ mutUTR-Fluc construct by deleting a fragment between Avrl and $\mathrm{Nrul}$ restriction sites, thereby deleting first $38 \mathrm{nt}$ in the $5^{\prime} \mathrm{UTR}$, containing also initiation codon for longest UORF. N-Bak full length $3^{\prime}$ UTR region, lacking an intron, was amplified by PCR from mouse embryo (E10.5) CDNA with forward $5^{\prime}$-TTCATCTAGAGGTTTGACCGGCTTCCTG-3' and reverse $5^{\prime}$-ATACGGATCCG CTGGGATTACAGCAGTGTG-3' primers. The full-length $3^{\prime}$ UTR region of N-Bak containing intron and full-length Bak $3^{\prime}$ UTR were amplified by PCR from mouse genomic DNA using forward N-Bak 5'-TTCATCTAGAGGTTTGACCGGCTTCCTG-3' or forward Bak 5'-CGTATCTAGACAGATTCTTCAGATCATGACTCC-3' primers with reverse $5^{\prime}$-ATACGGATCCGCTGGGATTACAGCAGTGTG-3' primer. Respective PCR fragments were digested with $\mathrm{Xbal} / \mathrm{BamHI}$ restrictases, purified and 
cloned into Xbal/BamHI sites of the pGL 4.13 vector (Promega, Madison, WI, USA), resulting in Fluc-3'UTR, Fluc- EJC- $3^{\prime}$ UTR and Fluc-Bak-3'UTR constructs. The $1 \mathrm{~kb}$ Xmal/Ppmul restriction fragments covering highly conserved miRNA sites in Fluc-3'UTR and Fluc-EJC-3'UTR were replaced with $0.8 \mathrm{~kb}$ Hpal fragment from pSIREN-dsRED DNR vector (Clontech Laboratories, Inc., Saint-Germain-en-Laye, France), resulting in Fluc-3'UTRmut and Fluc-EJC-3'UTRmut constructs. N-Bak $3^{\prime}$ UTRs with and without the addressed intron were also cloned into Xbal/BamHI sites of the $5^{\prime}$ UTR-Fluc and $5^{\prime}$ mutUTR-Fluc vector. This resulted in construct with natural $5^{\prime}$ - and $3^{\prime}$-UTRs, named $5^{\prime}$ UTR-Fluc-EJC- $3^{\prime}$ UTR and construct carrying mutated critical regulatory elements in both UTRs, 5'mutUTR-Fluc-3'UTR.

All constructs were verified by direct sequencing. N-Bak-L76E construct has been published previously. ${ }^{15}$ pEGFPF-C1-Dcp1 $\alpha$ plasmid is a kind gift from J Peränen (University of Helsinki, Helsinki, Finland; unpublished).

Cell culture and transfection. Neuro-2a and HeLa cells were grown in DMEM (Invitrogen, Carlsbad, CA, USA) containing 10\% fetal bovine serum (HyClone, Thermo Scientific, UK) and $100 \mu \mathrm{g} / \mathrm{ml}$ of Normocin (InvivoGen, Toulouse, France). Cells were transiently transfected with Lipofectamine 2000 (Invitrogen) according to the manufacturer's instructions. Neuro-2a cells were co-transfected in 24-well plate wells with pGL4.13 (Promega)-based Fluc and pGL4-73 (Promega) Rluc reporter plasmid mixtures in a 50:1 ratio and lysed $48 \mathrm{~h}$ later for dual luciferase assay or $36 \mathrm{~h}$ later for RNA isolation. HeLa cells were transfected in $6 \mathrm{~cm}$ dishes with the expression construct N-Bak-L76E and lysed after $36 \mathrm{~h}$ for immunoblot analysis.

Primary cell cultures and microinjection. Neonatal sympathetic SCG neurons were cultured on polyornithine-laminin (Sigma, St. Louis, MO, USA)coated dishes or glass coverslips in the Neurobasal medium containing B27 supplement (Invitrogen) and $30 \mathrm{ng} / \mathrm{ml}$ mouse 2.5S NGF (Promega). The cultures were maintained with NGF or deprived at 5 to 6 days in vitro (DIV) for 24 or $48 \mathrm{~h}$ of NGF by adding fresh medium with $2 \mu \mathrm{g} / \mathrm{ml}$ of function-blocking anti-NGF antibodies MAB5260Z (Merck Millipore, Billerica, MA, USA) and $25 \mu \mathrm{g} / \mathrm{ml}$ pan-caspase inhibitor boc-aspartyl(OMe)-fluoromethylketone (BAF) (Calbiochem/EMD Biosciences, Darmstadt, Germany). Microinjection was performed as published previously. ${ }^{15,16}$ For Dual Luciferase assay, SCG neurons were microinjected with the following expression plasmid mixtures: $10 \mathrm{ng} / \mu \mathrm{l}$ of Fluc reporter in $\mathrm{pGL} 4.13$ and $5 \mathrm{ng} / \mu \mathrm{l}$ of Rluc reporter in pGL4.73. To identify successfully injected neurons, $5 \mathrm{ng} / \mu \mathrm{l}$-eGFP-N1 (Invitrogen) plasmid was also included. Approximately 220-230 neurons were injected per each plasmid combination. pEGFPF-C1-Dcp $1 \alpha$ plasmid was injected at a concentration of $10 \mathrm{ng} / \mu \mathrm{l}$, the neurons were grown with $5 \mu \mathrm{M}$ of pan-caspase inhibitor Q-VD-OPh (R\&D Systems, Minneapolis, MN, USA) for $24 \mathrm{~h}$ and then fixed for immunostaining.

Cortical neurons were cultured as publishedpreviously. ${ }^{16}$ In cell stress induction experiments, etoposide (Sigma) at $4 \mu \mathrm{g} / \mathrm{ml}$ or thapsigargin (Molecular Probes, Eugene, OR, USA) at $10 \mathrm{nM}$ and caspase inhibitor Q-VD-OPh at $5 \mu \mathrm{M}$ were added to culture medium for $24 \mathrm{~h}$ or other indicated periods. For immunoblot or mass spectrometry analysis, cells from 40 sympathetic ganglia or $\sim 3 \times 10^{6}$ cells from cortical neuron cultures were used for sample preparation.

Immunoblot analysis. Cells were incubated on ice in the lysis buffer containing $150 \mathrm{mM} \mathrm{NaCl}, 50 \mathrm{mM}$ Tris- $\mathrm{HCl}, \mathrm{pH}$ 7.5, $1 \mathrm{mM}$ PMSF, $1 \times$ PhosSTOP phosphatase inhibitor cocktail solution (Roche Applied Science, Burgess Hill, UK; 04906845001), $100 \mu / / \mathrm{ml}$ protease inhibitor cocktail (Sigma 8340), 1\% Na-deoxycholate, $1 \% \mathrm{NP}-400$ and $0.1 \%$ SDS, collected to microtube and homogenized through the $25 \mathrm{G}$ needle with 6 strokes. Then, $5 \times$ Laemmli sample buffer was added, the lysates were boiled for $5 \mathrm{~min}$ and cooled on ice for $2 \mathrm{~min}$ before centrifugation at maximum speed for $8 \mathrm{~min}$. Next, $1 / 2$ from neuronal cell culture samples, $1 / 4$ of Neuro-2a and 1/8 of HeLa cell culture samples were loaded to gel. Samples were run in 15\% SDS-PAGE gels followed by blotting onto nitrocellulose membranes or direct fixation and gel staining. Nitrocellulose membranes were blocked for $1 \mathrm{~h}$ at room temperature (RT) with 5\% BSA-TBST (TBS-0.1\% Tween-20). Anti-Bak (Sigma, B-5897) or anti-P-elF2 $\alpha$ (Cell Signaling, Hitchin, UK; S 3398) primary antibodies and HRP-donkey anti-rabbit secondary antibodies (GE Healthcare, Little Chalfont, UK) in blocking buffer were used to detect N-Bak or P-elF2a, respectively. SuperSignal West Pico Chemiluminecent Substrate (Pierce Biotechnology, Rockford, IL, USA) and LAS3000 imager (Fujifilm, Tokyo, Japan) were used to develop immunoblot signals. For reprobing, the filters were washed with $62.5 \mathrm{mM}$ Tris- $\mathrm{HCl}, \mathrm{pH} 6.8$, containing $2 \%$ SDS and
$100 \mathrm{mM}$ 2-mercaptoethanol for $15 \mathrm{~min}$ at $+55^{\circ} \mathrm{C}$ and continued with several washings at RT with PBS and TBST.

RT-PCR and quantitative PCR analysis. Total RNA from transfected Neuro-2a cells was isolated with NucleoSpin RNA II RNA isolation kit (Macherey-Nagel, Düren, Germany) according to the manufacturer's instructions. DNase treatment was performed separately, $50 \mu \mathrm{l}$ DNase treatment reaction was kept at $37^{\circ} \mathrm{C}$ for $20 \mathrm{~min}$ containing $5 \mu \mathrm{l} \mathrm{RQ} 1$ DNase buffer, $2 \mu \mathrm{l}$ RNasine Ribonuclease Inhibitor $40 \mathrm{U} / \mu \mathrm{l}$ stock and RQ1 RNase-Free DNase $1 \mathrm{U} / \mu \mathrm{l}$ stock (all from Promega). RNA was cleaned with RNA Clean-up kit (Macherey-Nagel). RNA at $1 \mu \mathrm{g}$ was used for cDNA synthesis in the $20 \mu \mathrm{l}$ reaction volume using Transcriptor First Strand CDNA Synthesis kit with oligo(dT) primers (Roche Diagnostics, Mannheim, Germany). For common PCR, 1/10 of cDNA was used with Phusion High Fidelity DNA Polymerase (Finnzymes, Vantaa, Finland) with forward $5^{\prime}$-TTCATCTAGAGGTTTGACCGGCTTCCTG-3' and reverse $5^{\prime}$-ACCATGCAATGTTGGGGTAT- $3^{\prime}$ primers to detect correct splicing of the reporter transcripts, as shown by the amplicon length of $450 \mathrm{nt}$. PCR products were analyzed in $2 \%$ gel electrophoresis with GeneRuler $1 \mathrm{~kb}$ DNA Ladder (Thermo Fisher Scientific, Rockford, IL, USA). Quantitative PCR was performed essentially as published, ${ }^{16}$ except that primer annealing at $58^{\circ} \mathrm{C}$ for $10 \mathrm{~s}$ was used. Fluc reporter transcript levels were detected with forward $5^{\prime}$-TGCAAAAGATCCT CAACGTG- $3^{\prime}$ and reverse $5^{\prime}$-AATGGGAAGTCACGAAGGTG-3' primers; RLuc transcript levels with forward $5^{\prime}$-CCTGATCAAGAGCGAAGAGG-3' and reverse $5^{\prime}$-GTAGGCAGCGAACTCCTCAG-3' primers; and Cyclophilin G (NM_004792) levels with forward $5^{\prime}$-CAATGGCCAACAGAGGGAAG- $3^{\prime}$ and reverse $5^{\prime}$-CCAAAA ACAACATGATGCCCA-3' primers. Acquired $\mathrm{Cp}$ values of Fluc and Rluc were normalized to the Cyclophilin $G$ levels to ensure equal loading of the material. Thereafter, Fluc transcript levels were normalized to Rluc levels. Data were acquired from three independent biological replicas.

Luciferase reporter assay. Luciferase activity assay was performed using Dual-Luciferase Reporter Assay System (Promega) as published earlier. ${ }^{16}$ Briefly, $48 \mathrm{~h}$ after microinjections, enhanced green fluorescent protein (eGFP)-positive living neurons were counted, resulting in average 180-210 positive cells per experimental point. The neurons were collected to the microtubes and lysed in $20 \mu \mathrm{l}$ of $1 \times$ passive lysis buffer (Promega). Neuro-2a cells were lysed $48 \mathrm{~h}$ after transfections in $300 \mu \mathrm{l}$ of $1 \times$ passive lysis buffer. The relative luciferase activity (ratio of Fluc/Rluc) was determined with GloMax 20/20 luminometer (Promega). In neurons, the ratio of Fluc/Rluc was normalized to the number of eGFP-positive neurons for each experimental point. Statistical analysis was performed by using GraphPad InStat 3 program (GraphPad Software, Inc., La Jolla, CA, USA).

In situ hybridization. For in situ hybridization, sympathetic neurons were seeded to polyornithine-laminin-coated glass coverslips with NGF for 5 DIV, then deprived of NGF for $24 \mathrm{~h}$ or not deprived. The neurons were fixed with $4 \%$ PFA and $5 \mathrm{mM} \mathrm{MgCl} 2$ in PBS, acetylated with $0.25 \%$ acetic anhydride in $0.1 \mathrm{M}$ triethanolamine buffer ( $\mathrm{pH} 8.0$ ), washed once with $5 \mathrm{mM} \mathrm{MgCl}$-PBS buffer, permeabilized with $0.1 \%$ Triton $\mathrm{X}-100$ in PBS, washed with $5 \mathrm{mM} \mathrm{MgCl}-\mathrm{PBS}$, then two times with $5 \times \mathrm{SSC}, \mathrm{pH} 5.0$, and incubated in prehybridization buffer (50\% formamide, $5 \times \mathrm{SSC}, \mathrm{pH} 5.0)$ for $1 \mathrm{~h}$ at RT. N-Bak mRNA in situ hybridization was carried out for $16 \mathrm{~h}$ at $60^{\circ} \mathrm{C}$, in hybridization buffer (10\% dextrane sulfate, $50 \%$ formamide, $2 \times$ SSC, $2 \mathrm{mM}$ vanadyl-ribonucleoside complexes solution (Sigma 94742), $50 \mathrm{mM}$ phosphate buffer, $\mathrm{pH} 7.4$ ) in the presence of $5 \mathrm{pmol}$ of $5^{\prime}-3^{\prime}$ digoxigenin-labeled antisense or sense LNA-based DNA oligonucleotides purchased from Exiqon A/S (Vedbaek, Denmark). Antisense oligonucleotide, specific to exon N sequence, was $5^{\prime}$-CTGTGCATGTTGCTGCTG GC-3'and sense oligonucleotide with opposite direction was $5^{\prime}$-GCCAGCAGCAA CATGCACAG- $3^{\prime}$. Slides were washed once at $60^{\circ} \mathrm{C}$ with preheated washing buffer (65\% formamide, $2 \times$ SSC, pH 5.0, 0.1\% Tween-20) for 20 min and then at RT for 10 min with $2 \times \mathrm{SSC} / 0.1 \%$ Tween-20, $2 \times 5 \mathrm{~min}$ with $1 \times \mathrm{SSC}$ and $2 \times 5$ min with $0.1 \times$ SSC.

Immunostaining. In situ hybridized samples were incubated for $1 \mathrm{~h}$ at RT in the blocking buffer ( $1 \% \mathrm{BSA}$ in $150 \mathrm{mM} \mathrm{NaCl}, 100 \mathrm{mM}$ Tris- $\mathrm{HCl}, \mathrm{pH} 7.4)$ and overnight in same buffer with primary antibodies: horseradish peroxidaseconjugated sheep anti-digoxigenin (Roche Applied Science 11207733910), with or without mouse monoclonal anti-Dcp1 $\alpha$ (Abnova, Taipei, Taiwan; M06, clone 3G4). Cells were rinsed with $1 \times$ TBS and signal was amplified for $5 \mathrm{~min}$ in the amplification buffer (1:200 diluted biotinyl-tyramine, ${ }^{52} 0.01 \%$ hydrogen peroxide 
diluted in $100 \mathrm{mM}$ Tris- $\mathrm{HCl}, \mathrm{pH}$ 8.0). After three washings with TBST, the slides were incubated with Alexa 488-conjugated streptavidin (Invitrogen) in the blocking buffer for $2 \mathrm{~h}$ at RT in dark, followed by additional washings with TBST. GFPDcp1 $\alpha$-overexpressing cells were fixed with $4 \% \mathrm{PFA}, 5 \mathrm{mM} \mathrm{MgCl} 2$ in PBS for 15 min at RT, washed two times with $1 \times \mathrm{PBS} / 5 \mathrm{mM} \mathrm{MgCl}_{2}$ and treated as in situ hybridized samples except that mouse monoclonal anti-DCP1 $\alpha$ antibodies in the blocking buffer were used and signal was not amplified. Alexa 568-labeled antimouse secondary antibodies (Molecular Probes/Invitrogen) were used to detect Dcp1 $\alpha$ primary antibodies. Samples were mounted into Prolong Gold Antifade reagent (Molecular Probes) and stored at $+4^{\circ} \mathrm{C}$. Each experimental group was analyzed on three independent coverslips.

Immunofluorescence analysis. The fluorescent images were acquired using the confocal microscope TCS SP5 (Leica Microsystems, Wetzlar, Germany) equipped with LAS AF 1.82. The objective was Leica HCX PL APO $63 \times / 1.3$ GLYC CORR CS $\left(21^{\circ} \mathrm{C}\right)$. The laser for the fluorescent images was OPSL $488 \mathrm{~nm} /$ $270 \mathrm{~mW}$ with the beam splitter RSP 500. Doubly labeled cells were imaged in sequential mode with lasers OPSL $488 \mathrm{~nm} / 270 \mathrm{~mW}$ and $\mathrm{HeNe} 633 \mathrm{~nm} / 12 \mathrm{~mW}$ and beam splitter DD 488/561. For the transmitted light images, the Dodt gradient contrast system was used. The 3D images were deconvoluted by AutoQuant AutoDeblur 3D Blind Deconvolution software (Media Cybernetics, Inc., Rockville, MD, USA). Deconvoluted images were identically processed with ImageJ and Photoshop CS5 (Adobe Systems, Inc., San Jose, CA, USA) programs.

Mass spectrometry analysis. For mass spectrometry analysis, total cel lysates were separated in $15 \%$ polyacrylamid gel, the gels were fixed in $50 \%$ ethanol, 10\% acetic acid in water for $1 \mathrm{~h}$ and with $50 \%$ methanol, $10 \%$ acetic acid in water overnight at room temperature. Gels were stained in $0.1 \%$ Coomassie blue R250, 20\% methanol, $10 \%$ acetic acid solution for $3 \mathrm{~h}$ at RT and destained in $50 \%$ methanol, $10 \%$ acetic acid by changing buffer after every 30 min for 6 to 7 times. Gels were equilibrated in $5 \%$ acetic acid storage buffer. By using molecular weight markers as the landmarks, areas surrounding the position of $20 \mathrm{kDa}$, but excluding $25 \mathrm{kDa}$ (the position of Bak), $15 \mathrm{kDa}$ and neighboring lanes were cut out from the gels by clean sterile blades and gel pieces were stored separately in the sterile microtubes in storage buffer. Further in gel digestion, ${ }^{53,54}$ NanoLC-MS/MS analysis, peptide identification and peptide quantification were performed as described earlier. ${ }^{53}$

\section{Conflict of Interest}

The authors declare no conflict of interest.

Acknowledgements. Congjun Zheng is acknowledged for the excellent technical work. We thank Cyril Boulègue (Max Planck Institute of Biochemistry, Microchemistry Core Facility, Mass Spectrometry Service, Martinsried, Germany) for performing mass spectrometry analysis. Stefan Hüttelmaier (University of Halle, Germany) is acknowledged for the generous gift of anti-Dcp $1 \alpha$ antibodies and Jukka Kallijärvi and Johan Peränen (University of Helsinki, Helsinki, Finland) are thanked for sharing biotinyl-tyramine and pEGFPF-C1-Dcp1 $\alpha$ plasmid, respectively. This study was financed by the Academy of Finland program 11186236 (Finnish Centre of Excellence Program 2008-2013).

1. lacono M, Mignone F, Pesole G. UAUG and UORFs in human and rodent 5'untranslated mRNAs. Gene 2005; 349: 97-105.

2. Morris DR, Geballe AP. Upstream open reading frames as regulators of mRNA translation. Mol Cell Biol 2000; 20: 8635-8642.

3. Araujo PR, Yoon K, Ko D, Smith AD, Qiao M, Suresh $U$ et al. Before it gets started: regulating translation at the $5^{\prime}$ UTR. Comp Funct Genomics 2012; 2012: 475731

4. Fabian MR, Sonenberg N, Filipowicz W. Regulation of mRNA translation and stability by microRNAs. Annu Rev Biochem 2010; 79: 351-379.

5. Djuranovic S, Nahvi A, Green R. A parsimonious model for gene regulation by miRNAs Science 2011; 331: 550-553.

6. Huntzinger $\mathrm{E}$, Izaurralde $\mathrm{E}$. Gene silencing by microRNAs: contributions of translational repression and mRNA decay. Nat Rev Genet 2011; 12: 99-110.

7. Le Hir H, Seraphin B. EJCs at the heart of translational control. Cell 2008; 133: 213-216.

8. Isken O, Kim YK, Hosoda N, Mayeur GL, Hershey JW, Maquat LE. Upf1 phosphorylation triggers translational repression during nonsense-mediated mRNA decay. Cell 2008; 133 314-327.
9. You KT, Li LS, Kim NG, Kang HJ, Koh KH, Chwae YJ et al. Selective translational repression of truncated proteins from frameshift mutation-derived mRNAs in tumors. PLoS Biol 2007; 5: e109.

10. Lee $\mathrm{HC}$, Oh N, Cho H, Choe J, Kim YK. Nonsense-mediated translational repression involves exon junction complex downstream of premature translation termination codon. FEBS Lett 2010; 584: 795-800.

11. Westphal D, Dewson G, Czabotar PE, Kluck RM. Molecular biology of Bax and Bak activation and action. Biochim Biophys Acta 2011; 1813: 521-531.

12. Martinou J, Youle R. Mitochondria in apoptosis: Bcl-2 family members and mitochondrial dynamics. Dev Cell 2011; 21: 92-101.

13. Vaux DL. Apoptogenic factors released from mitochondria. Biochim Biophys Acta 2011; 1813: $546-550$.

14. Tait SW, Green DR. Mitochondria and cell death: outer membrane permeabilization and beyond. Nat Rev Mol Cell Biol 2010; 11: 621-632.

15. Sun YF, Yu LY, Saarma M, Timmusk T, Arumae U. Neuron-specific Bcl-2 homology 3 domain-only splice variant of Bak is anti-apoptotic in neurons, but pro-apoptotic in non-neuronal cells. J Biol Chem 2001; 276: 16240-16247.

16. Jakobson M, Lintulahti A, Arumae U. mRNA for N-Bak, a neuron-specific BH3-only splice isoform of Bak, escapes nonsense-mediated decay and is translationally repressed in the neurons. Cell Death Dis 2012; 3: e269.

17. Uo T, Kinoshita $\mathrm{Y}$, Morrison RS. Neurons exclusively express N-Bak, a BH3 domain-only Bak isoform that promotes neuronal apoptosis. J Biol Chem 2005; 280: 9065-9073.

18. Wong HK, Fricker M, Wyttenbach A, Villunger A, Michalak EM, Strasser A et al. Mutually exclusive subsets of BH3-only proteins are activated by the p53 and c-Jun N-terminal kinase/c-Jun signaling pathways during cortical neuron apoptosis induced by arsenite. Mol Cell Biol 2005; 25: 8732-8747.

19. Putcha GV, Harris CA, Moulder KL, Easton RM, Thompson CB, Johnson Jr EM. Intrinsic and extrinsic pathway signaling during neuronal apoptosis: lessons from the analysis of mutant mice. J Cell Biol 2002; 157: 441-453.

20. Wright KM, Deshmukh M. Restricting apoptosis for postmitotic cell survival and its relevance to cancer. Cell Cycle 2006; 5: 1616-1620.

21. Kedersha N, Anderson P. Mammalian stress granules and processing bodies. Methods Enzymol 2007; 431: 61-81.

22. Anderson P, Kedersha N. RNA granules: post-transcriptional and epigenetic modulators of gene expression. Nat Rev Mol Cell Biol 2009; 10: 430-436.

23. Anderson P, Kedersha N. Stress granules. Curr Biol 2009; 19: R397-R398.

24. Thomas MG, Loschi M, Desbats MA, Boccaccio GL. RNA granules: the good, the bad and the ugly. Cell Signal 2011; 23: 324-334.

25. Happo L, Strasser A, Cory S. BH3-only proteins in apoptosis at a glance. J Cell Sci 2012; 125: $1081-1087$.

26. Hershey JW. Translational control in mammalian cells. Annu Rev Biochem 1991; 60: 717-755.

27. Dever TE, Feng L, Wek RC, Cigan AM, Donahue TF, Hinnebusch AG. Phosphorylation of initiation factor 2 alpha by protein kinase GCN2 mediates gene-specific translational control of GCN4 in yeast. Cell 1992; 68: 585-596.

28. Deckwerth TL, Elliott JL, Knudson CM, Johnson Jr EM, Snider WD, Korsmeyer SJ. BAX is required for neuronal death after trophic factor deprivation and during development. Neuron 1996; 17: 401-411.

29. Deshmukh M, Johnson Jr EM. Evidence of a novel event during neuronal death: development of competence-to-die in response to cytoplasmic cytochrome c. Neuron 1998; 21: 695-705.

30. Putcha GV, Deshmukh M, Johnson Jr EM. BAX translocation is a critical event in neuronal apoptosis: regulation by neuroprotectants, BCL-2, and caspases. J Neurosci 1999; 19: 7476-7485

31. Martinou I, Desagher S, Eskes R, Antonsson B, Andre E, Fakan S et al. The release of cytochrome $\mathrm{c}$ from mitochondria during apoptosis of NGF-deprived sympathetic neurons is a reversible event. J Cell Biol 1999; 144: 883-889.

32. Kristiansen M, Menghi F, Hughes R, Hubank M, Ham J. Global analysis of gene expression in NGF deprived sympathetic neurons identifies molecular pathways associated with cell death. BMC Genomics 2011; 12: 551

33. Imaizumi K, Tsuda M, Imai Y, Wanaka A, Takagi T, Tohyama M. Molecular cloning of a novel polypeptide, DP5, induced during programmed neuronal death. J Biol Chem 1997; 272: $18842-18848$

34. Towers E, Gilley J, Randall R, Hughes R, Kristiansen M, Ham J. The proapoptotic dp5 gene is a direct target of the MLK-JNK-c-Jun pathway in sympathetic neurons. Nucleic Acids Res 2009; 37: 3044-3060

35. Whitfield J, Neame SJ, Paquet L, Bernard O, Ham J. Dominant-negative c-Jun promotes neuronal survival by reducing BIM expression and inhibiting mitochondrial cytochrome c release. Neuron 2001; 29: 629-643.

36. Putcha GV, Moulder KL, Golden JP, Bouillet P, Adams JA, Strasser A et al. Induction of $\mathrm{BIM}$, a proapoptotic $\mathrm{BH} 3-$ only $\mathrm{BCL}-2$ family member, is critical for neuronal apoptosis. Neuron 2001; 29: 615-628.

37. Besirli CG, Wagner EF, Johnson Jr EM. The limited role of NH2-terminal c-Jun phosphorylation in neuronal apoptosis: identification of the nuclear pore complex as a potential target of the JNK pathway. J Cell Biol 2005; 170: 401-411. 
38. McGlincy NJ, Tan LY, Paul N, Zavolan M, Lilley KS, Smith CW. Expression proteomics of UPF1 knockdown in HeLa cells reveals autoregulation of hnRNP A2/B1 mediated by alternative splicing resulting in nonsense-mediated mRNA decay. BMC Genomics 2010; 11: $565-2164-11-565$

39. Kozak M. Pushing the limits of the scanning mechanism for initiation of translation. Gene 2002; 299: 1-34.

40. Rahim G, Araud T, Jaquier-Gubler P, Curran J. Alternative splicing within the elk-1 5 ' untranslated region serves to modulate initiation events downstream of the highly conserved upstream open reading frame 2. Mol Cell Biol 2012; 32: 1745-1756.

41. Warnakulasuriyarachchi $\mathrm{D}$, Ungureanu $\mathrm{NH}$, Holcik M. The translation of an antiapoptotic protein HIAP2 is regulated by an upstream open reading frame. Cell Death Differ 2003; 10 : 899-904.

42. Calvo SE, Pagliarini DJ, Mootha VK. Upstream open reading frames cause widespread reduction of protein expression and are polymorphic among humans. Proc Natl Acad Sci USA 2009; 106: 7507-7512

43. Wells SE, Hillner PE, Vale RD, Sachs $A B$. Circularization of mRNA by eukaryotic translation initiation factors. Mol Cell 1998; 2: 135-140.

44. Gebauer F, Hentze MW. Molecular mechanisms of translational control. Nat Rev Mol Cell Biol. 2004; 5: 827-835.

45. Kole AJ, Swahari V, Hammond SM, Deshmukh M. miR-29b is activated during neuronal maturation and targets BH3-only genes to restrict apoptosis. Genes Dev 2011; 25: 125-130.

46. Eulalio A, Behm-Ansmant I, Izaurralde E. P bodies: at the crossroads of post-transcriptional pathways. Nat Rev Mol Cell Biol 2007; 8: 9-22.

47. Buchan JR, Parker R. Eukaryotic stress granules: the ins and outs of translation. Mol Cell 2009; 36: 932-941.
48. Zurla C, Lifland AW, Santangelo PJ. Characterizing mRNA interactions with RNA granules during translation initiation inhibition. PLoS One 2011; 6: e19727.

49. Carbonaro M, O'Brate A, Giannakakou P. Microtubule disruption targets HIF-1alpha mRNA to cytoplasmic P-bodies for translational repression. J Cell Biol 2011; 192 83-99.

50. Lohse I, Reilly P, Zaugg K. The CPT1C $5^{\prime}$ UTR contains a repressing upstream open reading frame that is regulated by cellular energy availability and AMPK. PLoS One 2011; 6: e21486.

51. Zeitelhofer M, Karra D, Macchi P, Tolino M, Thomas S, Schwarz M et al. Dynamic interaction between $\mathrm{P}$-bodies and transport ribonucleoprotein particles in dendrites of mature hippocampal neurons. J Neurosci 2008; 28: 7555-7562.

52. Adams JC. Biotin amplification of biotin and horseradish peroxidase signals in histochemical stains. J Histochem Cytochem 1992; 40: 1457-1463.

53. Schiller HB, Friedel CC, Boulegue C, Fassler R. Quantitative proteomics of the integrin adhesome show a myosin II-dependent recruitment of LIM domain proteins. EMBO Rep 2011; 12: 259-266.

54. Shevchenko A, Wilm M, Vorm O, Mann M. Mass spectrometric sequencing of proteins silverstained polyacrylamide gels. Anal Chem 1996; 68: 850-858.

(c) (i) (2) (2) Cell Death and Disease is an open-access journal (c) published by Nature Publishing Group. This work is licensed under a Creative Commons Attribution-NonCommercialShareAlike 3.0 Unported License. To view a copy of this license, visit http://creativecommons.org/licenses/by-nc-sa/3.0/ 